\title{
PANDANGAN HUKUM ISLAM TERHADAP ADAT PERKAWINAN ENDOGAMI MASYARAKAT SADE
}

\author{
Heri Zulhadi ${ }^{1} \&$ Mohsi $^{2}$ \\ ${ }^{1}$ Pascasarjana Ilmu Falak UIN Walisongo Semarang. \\ ${ }^{2}$ STAI Miftahul Ulum Pamekasan \\ Email: Heryhyzad@gmail.com \\ Email:silamohsi@gmail.com
}

\begin{abstract}
Adat is a culture or custom of a particular society inherent and binding to every resident. While marriage is a strong covenant bond (mitsa $>$ qan ghali> zhan) between a man and woman to live together. Endogamy is a mixed marriage within the sphere of kinship it self, whether it be inter ethnic, clan, tribe, or kinship within the kinship. The endogamous marriage done by the traditional Sade Rembitan Central Lombok do it from amongst his immediate family in other words a cognate marriage conducted within the village and is not allowed to marry out. It is done by the Sade - Rembitan society driven by several factors namely, a deeply embedded culture among families, keeping and preserving kinship, to guard property or inheritance, and most embedded in their heads is to inherit parental counsel. There are several types of endogamy marriages performed by the Sade community in general that is, by way of tepedait (meeting), in this case the parents are meeting their children with other families who are still within the family or relatives own. The matchmaking is usually done by both parents who are concerned when the child is young. When the child is matured then the marriage is held. As an attempt to maintain a kinship system closely related to the term merariq mbait kance diriq (endogamy).
\end{abstract}

Keyword : Culture, Marriage, and Endogamy.

\section{PENDAHULUAN}

Keanekaragaman suku dengan latar belakang kebudayaan dan adat yang berbeda menjadi ciri khas bangsa Indonesia dan merupakan manifestasi unsur kebhinekaan. Pada kenyataannya, penduduk Indonesia terdiri dari berbagai suku, budaya, adat baik mayoritas dan minoritas yang membaur dengan budaya adat lainnya. Bangsa asing yang pernah datang dan berada di Indonesia inilah yang membawa pengaruh dalam kebudayaan dan adat istiadat Indonesia. 
Masyarakat berbaur dalam kehidupan sehari-hari dengan masyarakat lainnya dalam melangsungkan interaksi kehidupan baik dari segi bisnis, kekerabatan, adat, sosial kemasyarakatan, dan sebagainya.

Setiap makhluk diciptakan dengan cara berpasang-pasangan. Begitu juga manusia, jika pada makhluk lain dalam berpasangan tidak memerlukan tata cara dan peraturan tertentu, maka lain halnya dengan manusia. Pada manusia terdapat beberapa ketentuan yang merupakan peraturan dalam memilih pasangan dan untuk hidup bersama pasangan. Baik itu peraturan agama, adatistiadat, tradisi, maupun sosial kemasyarakatan.

Hal ini sejalan dengan falsafah negara, yaitu Pancasila dan Bhineka Tunggal Ika. Allah swt. memang telah menciptakan manusia dari seorang lakilaki dan perempuan, berbangsa-bangsa dan bersuku-suku sesuai dengan firman Allah dalam surat Al-Hujurat ayat: 13 yang berbunyi:
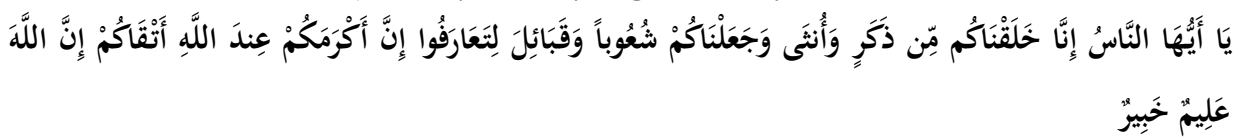

Artinya : Hai manusia, sesungguhnya Kami menciptakan kamu dari seorang laki-laki dan seorang perempuan dan menjadikan kamu berbangsa-bangsa dan bersuku-suku supaya kamu saling kenal-mengenal. Sesunggubnya orang yang paling mulia di antara kamu disisi Allah ialah orang yang paling taqwa di antara kamu.Sesunggubnya Allah Maba Mengetabui lagi Maba Mengenal. ${ }^{1}$

Di dalam berkehidupan bermasyarakat terdapat sebuah adat kebiasaan yang berlaku pada suatu masyarakat yang sangat kental dan dijunjung tinggi seperti adat istiadat masyarakat tradisional Sade dalam bentuk perkawinan endogami (perkawinan serumpun/perkawinan yang hanya dilakukan dengan kerabat dekatnya dalam satu dusun). Perkawinan yang dilakukan oleh masyarakat Sade tidak membolehkan untuk menikah keluar dusun. Pernikahan yang dilakukan hanya dilakukan dengan kerabat dekat yang ada di lingkungan Sade tersebut.

Sementara di dalam hukum Islam tidak ada yang menjelaskan bahwa pernikahan itu harus dengan kerabat dekat, sesama suku, anggota keluarga, sesama desa maupun dusun. Akan tetapi, manusia bebas memilih pasangan untuk melakukan pernikahan sesuai dengan mukafa'ah (kecocokan) pada pasangan pengantin yang hendak melakukan pernikahan. Dalam surat Yasin ayat 36 Allah swt. Berfirman yang Artinya: Maha suci tuhan yang telah menciptakan

\footnotetext{
${ }^{1}$ Departemen Agama Republik Indonesia. Al-Qur'an dan Terjemahnya, (Semarang : PT. Karya Toha Putra.1995), QS. Al-Hujurat (43):13.
} 
pasangan semuanya, baik dari apa yang ditumbubkan oleh bumi dan dari diri mereka maupun dari apa yang tidak mereka ketahui. ${ }^{2}$

Persoalan yang menarik dalam kajian ini adalah pernikahan masyarakat Sade-Rembitan yang hanya dilakukan oleh warga serumpun/sesama dusun dan kerabat dekatnya saja. Ketika terjadi pernikahan keluar yang tidak sesama dusun atau sukunya yang dilakukan oleh masyarakat Sade, masyarakat yang melakukan pernikahan keluar tersebut diberikan semacam sanksi moral. Seperti tidak dibenarkan atau diindahkan melakukan adat-adat yang biasanya berlaku seperti roah, nyongkolan / begendang beleq dan lain sebagainya. Jika pihak yang bersangkutan mau melaksanakan adat pernikahan yang sudah ada dan dilayani oleh masyarakat seperti biasanya, yang bersangkutan harus membayar denda sesuai yang disepakati oleh masyarakat dan tokoh adat yang ada di sana. Metode yang digunakan dalam penulisan ini adalah metode deskriptif kualitatif. Metode deskriftif merupakan penelitian yang bertujuan menggambarkan dan menjelaskan antara adat budaya dan kebiasaan yang dijalankan oleh masyuarakat Sade - Rembitan Lombok Tengah dalam hal melaksanakan adat perkawinan (merariq) dalam pandangan hukum Islam. Sedangkan sumber kajian ini diambil dari beberapa buku-buku ilmiah, baik berupa jurnal dalam bentuk media cetak maupun elektronik yang dijadikan sebagai sumber referensi dan rujukan. Adapun tehnik pengumpulan data dalam penulisan ini adalah studi kepustakaan, wawancara dan observasi dengan hal yang terkait.

\section{Teorisasi Adat dalam berbagai sudut pandang}

Haji Dahlan Tamrin menjelaskan bahwa adat adalah suatu (amaliyah atau perkataan) yang terus menerus dilakukan oleh manusia lantaran dapat diterima akal dan secara berlanjut manusia mau mengulanginya. ${ }^{3}$ Dengan demikian, proses pembentukan adat adalah akumulasi dari pengulangan aktifitas yang berlangsung terus menerus, dan ketika pengulangan tersebut bisa membuat tertanam dalam hati individu, maka ia sudah memasuki wilayah muta'arrafat dan saat itu pulalah adat berubah menjadi kebiasaan, sehingga adat merupakan unsur yang muncul pertama kali dan dilakukan berulang-ulang lalu tertanam di dalam hati kemudian menjadi urf. ${ }^{4}$

Adat merupakan aturan, kebiasaan-kebiasaan yang tumbuh dan terbentuk dari suatu masyarakat atau daerah yang dianggap memiliki nilai dan

\footnotetext{
${ }^{2}$ Departemen Agama Republik Indonesia. Al-Qur'an dan Terjemahnya, (Semarang: PT. Karya Toha Putra.1995), QS. Yasin (36): 36.

${ }^{3}$ Dahlan Tamrin, Kaidah-Kaidah Hukum Islam Kulliyah Al-Khamsah, (Malang: UIN Maliki Press, 2010), h. 206.

${ }^{4}$ Dahlan Tamrin, Kaidah-Kaidah Hukum..., h. 208.
} 
dijunjung serta dipatuhi masyarakat pendukungnya. Di Indonesia aturan-aturan tentang segi kehidupan manusia tersebut menjadi aturan-aturan hukum yang mengikat. Seperti kaidah fiqh menjelaskan bahwa adat merupakan hukum.

العادة محكمة5

\section{Artinya: Adat merupakan patokan bukum.}

Adat bersifat mengikat dan mempunyai akibat hukum, sedangkan lembaga tidak mengikat dan mempunyai akibat hukum, di daerah Minahasa dan Maluku terdengar istilah adat kebiasaan, di daerah Batak Karo istilah adat jarang sekali terdengar, di situ dipakai istilah-istilah basa atau bicara yang merupakan kebiasaan dan kesusilaan. ${ }^{6}$ Adat telah melembaga dalam kehidupan masyarakat baik berupa tradisi, adat upacara dan lain-lain yang mampu mengendalikan perilaku warga masyarakat dengan perasaan senang atau bangga, dan peranan tokoh adat yang menjadi tokoh masyarakat menjadi cukup penting. Adat merupakan norma yang tidak tertulis, tetapi sangat kuat mengikat sehingga anggota-anggota masyarakat yang melanggar adat istiadat akan menderita, karena sanksi keras yang kadang-kadang secara tidak langsung dikenakan. Seperti halnya dengan semua sistim hukum di bagian lain di dunia ini, maka hukum adat itu senantiasa tumbuh dari suatu kebutuhan hidup yang nyata, cara hidup dan pandangan hidup, yang keseluruhannya merupakan kebudayaan masyarakat tempat hukum adat itu berlaku. Tidak mungkin suatu hukum tertentu yang asing bagi masyarakat itu dipaksakan atau dibuat, apabila hukum tertentu yang asing itu bertentangan dengan kemauan orang banyak dalam masyarakat yang bersangkutan atau tidak mencukupi rasa keadilan rakyat yang bersangkutan, pendeknya bertentangan dengan kebudayaan rakyat yang bersangkutan. ${ }^{7}$

Kaidah adat diambil dari realitas sosial kemasyarakatan bahwa semua cara hidup dan kehidupan itu dibentuk oleh nilai-nilai yang diyakini sebagai norma yang sudah berjalan sejak lama sehingga mereka memiliki pola hidup dan kehidupan sendiri secara khusus berdasarkan nilai-nilai yang sudah dihayati bersama. Jika ditemukan suatu masyarakat meninggalkan suatu amaliyah yang selama ini sudah biasa dilakukan, maka mereka sudah dianggap mengalami pergeseran nilai. ${ }^{8}$

\section{Dasar Hukum tentang Adat}

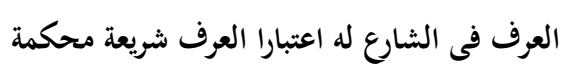

\footnotetext{
${ }^{5}$ Imam Jalaluddin As-Sayuti, Al-Isybâhu Wannazhâ iyr fil Furû', (Surabaya: Haromaen, 2007), h. 66.

${ }^{6}$ Bushar Muhammad, Asas-asas Hukum Adat (Suatu Pengantar), (Jakarta: Pradnya Paramita, 1983), h. 11.

${ }^{7}$ Ibid., h. 50

${ }^{8}$ Tamrin, Kaidah-Kaidah ... h. 203.
} 
Artinya : 'Urf merupakan syara' memiliki suatu penghargaan (bernilai hujjab) dan kaidah "urf merupakan dasar bukum yang telah dikokobkan."

Dalam al-qur'an juga dijelaskan dalam surat al-a'raf ayat 199 dan al-Nisa' ayat 19 yang berbunyi :

وعاشروهن بالمعروف

Artinya : Dan pergaulilah mereka dengan baik. ${ }^{10}$

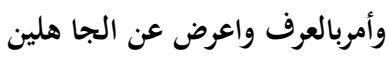

Artinya : Dan surublah orang untuk mengerjakan yang ma'ruf dan berpalinglah dari orangorang yang bodoh. ${ }^{11}$

Dari ayat diatas yang dimaksud dengan istilah 'urf atau kebiasaan dalam ayat ini adalah hal-hal yang sudah diketahui nilai baiknya dan wajib dikerjakan, artinya segala sesuatu yang diperintahkan oleh syari'at. ${ }^{12}$

Dalam hadits Rasulullah saw. juga dijelaskan sebagai berikut:

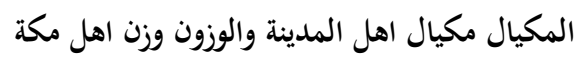

Artinya : Takaran itu milik penduduk Madinah, dan timbangan itu milik penduduk Makkah. ${ }^{13}$

Dalam hadits ini bisa diambil pemahaman bahwa titik tekan dalam hadits ini terletak pada penegasan nabi Muhammad saw. bahwa penduduk Madinah yang mayoritas berprofesi sebagai petani kurma dan padi dalam tradisi atau adat jual belinya diarahkan untuk tetap menggunakan takaran, sedang bagi wilayah yang mayoritas profesi penduduknya sebagai pedagang dalam transaksi jual belinya supaya tetap menggunakan timbangan. Hal ini memberikan pengertian bahwa nabi Muhammad saw. telah memberi legitimasi pada adat atau tradisi yang berkembang di kedua kota dan tidak bermaksud menghapus atau memaksa tradisi di satu kawasan harus diterapkan di kawasan lain jika kenyataannya tidak sesuai dengan kebutuhan masyarakat.

\section{Konsep Perkawinan}

\section{Terminologi Perkawinan}

Perkawinan dalam bahasa arab dikenal dengan istilah az-zawaj yang berasal dari bahasa arab yang akar katanya $z-w-j$ (j-و) yang memiliki makna "mengawinkan, memasangkan, menggabungkan." Dalam ungkapan bahasa Arab dikenal ungkapan yang mengatakan تزوجالكوم yang maksudnya "kelompok itu

\footnotetext{
${ }^{9}$ Tamrin, Kaidah-Kaidah ..., h. 205

${ }^{10}$ Tamrin, Kaidah-Kaidah ..., h. 210

${ }^{11}$ Tamrin, Kaidah-Kaidah ..., h. 209

12 Tamrin, Kaidah-Kaidah ..., h. 210

${ }^{13}$ Tamrin, Kaidah-Kaidah ...., h. 210
} 
saling berpasangan." ${ }^{\text {14 }}$ Pengertian perkawinan sebagaimana yang disebutkan di dalam Kompilasi Hukum Islam bahwa perkawinan menurut hukum Islam adalah pernikahan, yaitu akad yang sangat kuat atau mi>tsa $>$ qan gholi $>d$ rhan untuk mentaati perintah Allah dan melaksanakannya merupakan ibadah. ${ }^{15}$

Asnawi di dalam bukunya yang berjudul Dimensi-dimensi Syariah dari Teologi, Hukum, Akblak sampai Pemikiran memberikan pengertian terhadap pernikahan yaitu sebuah ikatan perjanjian (komitmen) antara lakai-laki dan perempuan untuk menjalin hidup berumah tangga dalam mencapai tujuan bersama yaitu bahagia di dunia dan akhirat. ${ }^{16}$ Pernikahan sebagai salah satu asas pokok yang paling utama dalam pergaulan atau masyarakat yang sempurna, pernikahan itu bukan saja merupakan jalan yang amat mulia untuk mengatur kehidupan rumah tangga dan keturunan, tetapi juga dapat dipandang sebagai satu jalan menuju pintu perkenalan antara suatu kaum dengan kaum lain, dan perkenalan itu akan menjadi jalan untuk menyampaikan pertolongan antara satu dengan yang lainnya. Perkawinan terjadi ketika setiap orang atau sesuatu saling berpasangan dengan yang lainnya.Karenanya, dua orang yang telah menjadi suami isteri disebut pasangan suami isteri. ${ }^{17}$ Begitu pula makna ungkapan seseorang, "saya memiliki sepasang merpati", yang berarti orang tersebut memiliki seekor merpati jantan dan betina. ${ }^{18}$ Pertalian pernikahan adalah pertalian yang seteguh-teguhnya dalam hidup dan kehidupan manusia. Buah dari terwujudnya tujuan pernikahan yaitu untuk mewujudkan kehidupan rumah tangga yang sakinah, mawaddah, dan rahmah. ${ }^{19}$

\section{Rukun Perkawinan}

Sebagaimana yang sering terjadi dan biasa dilakukan oleh mayoritas umat Islam di Indonesia bahwa perkawinan itu dilakukan oleh laki-laki dan perempuan dengan sebuah shighat (akad) nikah yang di-ijab-kan oleh wali mempelai perempuan yang kemudian di-qabul-kan (diterima) oleh mempelai laki-laki atau orang yang mewakili dan disaksikan oleh orang banyak sekurangkurangnya dua orang saksi. Pernikahan terbentuk oleh beberapa unsur yang di

\footnotetext{
${ }^{14}$ M. Shabbag, Hadiah Cinta.Kiat Islami merencanakan dan Membina Rumah Tangga Bahagia Selamanya, (Jakarta: Bania Publishing, 2011), h. 01.

${ }^{15}$ Undang-undang R. I No. 1 Tahun 1974 tentang Perkawinan \& Kompilasi Hukum Islam serta PERPU Tahun 2009 tentang Penyelenggaraan Ibadah Haji, (Surabaya: Kesindo Utama, 2010), h. 196.

${ }^{16}$ Asnawi,Dimensi-dimensi Syari'ah dari Teologi, Hukum, Akhlak sampai Pemikiran, (STAIN Tulungagung Press), h. 58.

${ }^{17}$ M. Shabbag, Hadiah..., h. 01.

${ }^{18}$ Shabbag, Hadiah..., h. 01

${ }^{19} \mathrm{H}$. Abdurrahman, Kompilasi Hukum Islam Islan di Indonesia, (Jakarta: Akademika Pressindo, 2004), h. 114.
} 
dalam Islam dikenal sebagai rukun yaitu shighat (akad) ijab qabul (akad), calon suami, calon istri, wali nikah, dan dua orang saksi. ${ }^{20}$

\section{Syarat-Syarat Perkawinan}

Syarat-syarat Perkawinan merupakan syarat-syarat yang harus ada pada unsur-unsur Perkawinan sehingga perbuatan Perkawinan dapat dikatakan sah. Apabila perbuatan Perkawinan dikatakan sah. Syarat-syarat yang harus ada pada Perkawinan ialah kedua belah pihak harus mumayyiz, tempat pelaksanaan ijab dan kabul harus berada dalam satu majlis, kalimat kabul tidak berbeda maksud dengan kalimat ijab, masing-masing dari kedua belah pihak yang melakukan akad adalah untuk melangsungkan akad pernikahan. ${ }^{21}$ Pernikahan atau perkawinan memang ada dan terbentuk karena unsur-unsurnya atau rukunrukunya telah terpenuhi. Meskipun demikian belum tentu dikatakan sah, karena unsur-unsur pembentuk sebuah pernikahan belum tentu memenuhi syaratsyarat yang telah ditentukan di dalam Islam yang lebih populer disebut sebagai syarat-syarat nikah atau syarat-syarat perkawinan. Syarat-syarat perkawinan tersebut ialah:

a) Shighat (akad), yaitu suatu pernyataan serah (ijab) dan terima (qabul) antara pihak wali perempuan dengan calon mempelai laki-laki. Ijab yang diucapkan oleh wali nikah dan qabul yang diucapkan oleh calon mempelai laki di dalam Kompilasi Hukum Islam pasal 27 disebutkan harus jelas, beruntun, dan tidak berselang waktu. ${ }^{22}$ Akad nikah tersebut harus menggunakan lafaz nikah, tazwij, atau terjemahan dari keduanya. ${ }^{23}$

b) Calon mempelai, Kompilasi Hukum Islam telah mensyaratkan perkawinan hanya boleh dilakukan oleh calon mempelai yang telah mencapai umur yaitu calon suami sekurang-kurangnya berumur 19 tahun dan calon istri sekurangkurangnya berumur 16 tahun dan antara calon suami dan calon istri yang akan melangsungkan pernikahan tersebut tidak ada halangan yang dapat menghalangi berlangsungnya pernikahan. Tidak hanya itu, Kompilasi Hukum Islam juga mensyaratkan bagi calon mempelai yang belum mencapai umur 21 tahun harus mendapat izin sebagaimana yang diatur dalam pasal 6 ayat (2), (3), (4), dan (5) UU No 1 Tahun 1974. Perkawinan yang dilakukan oleh calon mempelai tersebut harus didasarkan atas persetujuannya. Bentuk persetujuan calon mempelai perempuan dapat berupa pernyataan tegas dan nyata dengan tulisan, lisan, atau isyarat, tapi

\footnotetext{
${ }^{20}$ Abdurrahman, Kompilasi Hukum..., h. 116.

${ }^{21}$ H. Ahmad Wardi Muslich, Hukum Pidana Islam, (Jakarta: Sinar Grafika. 2005), h. 70.

${ }^{22}$ Abdurrahman, Kompilasi....., h. 119.

${ }^{23}$ Sulaiman Rasjid, Fiqih Islam, (Bandung: Sinar Baru Algesindo. 2006), h. 382.
} 
dapat juga berupa diam dalam arti selama tidak ada penolakan yang tegas. Untuk mengetahui persetujuan tersebut Pegawai Pencatat Nikah dapat menanyakan terlebih dahulu persetujuan calon mempelai dihadapan dua orang saksi. Apababila perkawinan tersebut tidak disetujui oleh salah seorang calon mempelai maka perkawinan itu tidak dapat dilangsungkan. ${ }^{24}$

c) Wali nikah, dalam pernikahan wali nikah merupakan rukun yang harus dipenuhi bagi calon mempelai wanita yang bertindak untuk menikahkannya. ${ }^{25} \mathrm{Hal}$ ini berdasarkan hadis Nabi saw. yang berbunyi:

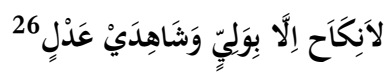

Artinya: "Tidak sah nikah kecuali dengan wali dan dua orang saksi yang adil."

Lebih lanjut Rasulullah saw. juga bersabda tentang pernikahan yang dilakukan oleh seorang perempuan tanpa seizin walinya adalah batal sebagaimana sabdanya yang berbunyi:

$$
27 \text { أَيَْا } 27
$$

Artinya: "Barangsiapa di antara perempuan yang menikah tidak dengan iæin walinya maka pernikahannya itu batal."

Kemudian terkait dengan perempuan yang menikahkan perempuan lain dan perempuan yang menikahkan dirinya sendiri Rasulullah saw. bersabda yang berbunyi:

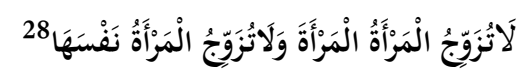

Artinya: "Janganlah perempuan menikabkan perempuan lain dan jangan pula seorang perempuan menikabkan dirinya sendiri."

Berdasarkan hadis-hadis tersebut di atas terlihat bahwa wali nikah harus ada dalam pernikahan dan sekaligus merupakan rukun dari pernikahan itu sendiri. Bagi wanita yang tidak punya wali atau ada walinya tapi adhal alias enggan maka wali bagi wanita tersebut sebagaimana yang disebutkan di dalam Kompilasi Hukum Islam ialah wali hakim. Lebih rinci Kompilasi Hukum Islam menyebutkan bahwa wali hakim baru dapat bertindak sebagai wali nikah apabila wali nasab tidak ada atau tidak mungkin menghadirkannya atau tidak diketahui tempat tinggalnya atau ghaib atau adhal atau enggan. Lebih lanjut disebutkan

${ }^{24}$ Abdurrahman, Kompilasi..., h. 117.

${ }^{25}$ Abdurrahman, Kompilasi Hukum..., h. 118.

${ }^{26}$ Ibnu Majah, Sunan Ibnu Majah Jilid III, (Lubnan: Darul Kutub Al-'Ilmiyah Beirut, 1971), h. 435 . 182.

${ }^{27}$ Al-Tirmizi, Sunan Al-Tirmizi Jilid III, (Lubnan: Daru Kutub Al-'Ilmiyah Bierut, 1971), h.

${ }^{28}$ Ibnu Majah, Sunan Ibnu Majah Jilid III..., h. 435. 
dalam hal wali adhal atau enggan maka wali hakim baru dapat bertindak sebagai wali nikah setelah ada putusan pengadilan agama tentang wali tersebut. ${ }^{29}$

Kompilasi Hukum Islam juga menyebutkan bahwa yang bertindak sebagai wali nikah ialah laki-laki yang memenuhi syarat hukum Islam yakni muslim, berakal, dan baligh. Wali nasab terdiri dari empat kelompok dalam urutan kedudukan, kelompok yang satu didahulukan dari kelompok yang lain sesuai erat tidaknya susunan kekerabatan dengan calon mempelai wanita. Empat kelompok tersebut ialah: 1) Kelompok kerabat laki-laki dari garis lurus ke atas yakni ayah, kakek dari pihak ayah dan seterusnya. 2) Kelompok kerabat saudara laki-laki kandung atau saudara laki-laki seayah dan keturunan laki-laki mereka. 3) kelompok kerabat paman, yakni saudara laki-laki kandung ayah, sauadara lakilaki ayah seayah dan keturunan laki-laki mereka. 4) Kelompok saudara laki-laki kandung kakek, saudara laki-laki kakek seayah dan keturunan laki-laki mereka. Apabila dalam satu kelompok wali nikah terdapat beberapa orang yang samasama berhak menjadi wali, maka yang paling berhak menjadi wali ialah yang lebih dekat derajat kekerabatannya dengan calon mempelai wanita. Namun apabila wali nikah yang paling berhak urutannya tidak memenuhi syarat sebagai wali nikah atau karena wali nikah itu menderita tuna wicara, tunu rungu, atau sudah udzur maka hak menjadi wali nikah bergeser kepada wali yang lain menurut derajat berikutnya. ${ }^{30}$

d) Saksi nikah, saksi dalam perkawinan merupakan rukun pelaksanaan akad nikah dan setiap perkawinan harus disaksikan oleh dua orang saksi, sedangkan saksi yang dapat ditunjuk menjadi saksi dalam akad nikah ialah seorang laki-laki muslim, adil, akil baligh, tidak terganggu ingatan, dantidak tuna rungu atau tuli. Saksi ini harus hadir dan menyaksikan secara langsung akad nikah serta menandatangani Akta Nikah pada waktu dan di tempat akad nikah dilangsungkan. ${ }^{31}$

\section{Konsep Endogami}

Dalam kamus ilmiah populer dijelaskan pengertian endogami, yaitu perkawinan campuran dalam lingkup kekerabatan sendiri. ${ }^{32}$ Sedang dalam kamus bahasa Indonesia dijelaskan bahwa endogami adalah prinsip perkawinan yang menghendaki pasangan dari lingkungan sendiri. ${ }^{33}$ Lebih jelasnya, endogami adalah suatu perkawinan antara etnis, $\underline{\text { klan, }} \underline{\text { suku, }}$, atau kekerabatan dalam

\footnotetext{
${ }^{29}$ Abdurrahman, Kompilasi..., h. 119.

${ }^{30}$ Abdurrahman, Kompilasi..., h. 118.

${ }^{31}$ Abdurrahman, Kompilasi..., h. 119.

${ }^{32}$ Risa Agustin, Kamus Ilmiah Populer Lengkap, (Surabaya: Serba Jaya), h. 107.

${ }^{33}$ Kamus Bahasa Indonesia untuk Pelajar, (Jakarta Timur: Badan Pengembangan dan Pembinaan Bahasa, Kementrian Pendidikan dan Kebudayaan, 2011), h. 115.
} 
lingkungan yang sama. ${ }^{34}$ Perkawinan endogami merupakan perkawinan antarkerabat atau perkawinan yang dilakukan antarsepupu (yang masih memiliki satu keturunan) baik dari pihak ayah sesaudara (patrilineal) atau dari ibu sesaudara (matrilineal). Kaum kerabat boleh menikah dengan saudara sepupunya karena mereka yang terdekat dengan garis utama keturunan dipandang sebagai pengemban tradisi kaum kerabat, perhatian yang besar dicurahkan terhadap silsilah atau genealogi. ${ }^{35}$

Perkawinan dilakukan dalam lingkungan rumpun, antara anggota yang satu (lelaki) dengan anggota yang lain (perempuan). Perkawinan tidak dilakukan di luar rumpun. Dengan kata lain, rumpun mengenal kawin endogami (endo = dalam). Kawin endogami yaitu kawin dalam lingkungan sendiri, merupakan suatu ajaran yang beralasan pada kepentingan persatuan dalam hubungan antarkeluarga, supaya dapat mempertahankan tanah tetap menjadi milik lingkungan sendiri (milik rumpun), beralasan kepentingan keamanan dan kepentingan-kepentingan sosial yang lain. ${ }^{36}$ Endogami merupakan prinsip perkawinan yg mengharuskan orang untuk mencari jodoh di lingkungan sosialnya sendiri.Misalnya, di lingkungan kerabat, lingkungan kelas sosial, atau lingkungan pemukiman. ${ }^{37}$

Istilah endogami sebenarnya memiliki arti yang relatif, sehingga kita selalu perlu menjelaskan apa batas-batasnya. Penentuan batas-batas tersebut tergantung pada budaya yang dipegang oleh setiap masyarakat yang tentunya akan berbeda antara masyarakat yang satu dengan masyarakat yang lain. Batasan itu dapat berupa endogami agama, endogami desa, endogami suku/keturunan, endogami ekonomi ataupun endogami kasta. Misalnya endogami agama yang merupakan larangan untuk melakukan perkawinan dengan seseorang yang memiliki agama yang berbeda dari agama yang kita anut.Seperti endogami kasta pada masyarakat $\underline{B a l i}$, adanya larangan untuk melakukan perkawinan dengan pihak dari luar kasta. ${ }^{38}$

\section{Perkawinan Endogami Masyarakat Adat Sasak Sade-Rembitan}

Dalam masyarakat Indonesia ada dua jenis landasan mempersatukan orang berdasarkan keturunan, yaitu garis keturunan yang dalam bahasa Belanda disebut altenerend dan dubbel unilateraal. Kedua garis keturunan ini merupakan

\footnotetext{
WITA.

${ }^{34}$ http://id.wikipedia.org/wiki/Endogami, diambil tanggal 13 Maret 2015, pukul 10.35

${ }^{35} \mathrm{http} / / /$ id.wikipedia.org/wiki/Endogami, diambil tanggal 13 Maret 2015, pukul 10.35

WITA.

${ }^{36}$ Bushar Muhammad, Asas-asas Hukum ..., (Jakarta: Pradnya Paramita, 1983), h. 35.

${ }^{37} \mathrm{http}: / /$ artikata.com/arti-326501-endogami.html, diambil tanggal 13 Maret 2015, pukul 10.35 WITA.

${ }^{38}$ http://id.wikipedia.org/wiki/Endogami, diambil tanggal 13 Maret 2015, pukul 10.35 WITA.
} 
bentuk-bentuk istimewa dalam menarik garis keturunan yang berasal dari yaitu yang dalam fase permulaannya terdapat dalam masyarakat hukum adat kebapaan..$^{39}$ Masyarakat hukum adat yang susunannya didasarkan atas pertalian keturunan menurut suatu garis altenerend adalah masyarakat hukum adat yang para anggotanya menarik garis keturunan berganti-ganti secara bergiliran melalui garis ayah maupun melalui garis ibu sesuai dengan bentuk perkawinan yang dialami oleh orang tua. ${ }^{40}$ Masyarakat hukum adat yang susunannya didasarkan atas pertalian keturunan menurut garis dubbel unilateral adalah masyarakat hukum adat yang para anggotanya menarik garis keturunan melalui garis ayah dan garis ibu jalin menjalin, dan hal itu sesuai dengan pandangan dari mereka yang bersangkutan dan tergantung pada hal apakah ia laki-laki atau perempuan.

Pengetahuan kita tentang susunan masyarakat hukum adat di atas ini menjadi dasar pengetahuan kita untuk menelaah hukum perkawinan adat dan hukum waris adat. Masyarakat hukum adat yang strukturnya bersifat teritorial, yaitu masyarakat hukum adat yang disusun berasaskan lingkungan daerah adalah masyarakat hukum adat yang para anggotanya merasa bersatu dan oleh sebab itu merasa bersama-sama merupakan kesatuan masyarakat hukum adat yang bersangkutan, karena ada ikatan antara mereka masing-masing dengan tanah tempat tinggal mereka. Landasan yang mempersatukan para anggota masyarakat hukum adat yang strukturnya bersifat teritorial adalah ikatan antara orang (yaitu anggota masing-masing masyarakat tersebut) dengan tanah yang didiaminya sejak kelahirannya, yang didiami oleh orang tuanya, yang didiami oleh neneknya, yang didiami oleh nenek moyangnya secara turun temurun.Ikatan dengan tanah menjadi inti asas teritorial itu.

Ada tiga jenis masyarakat hukum adat yang strukturnya bersifat teritorial yaitu :

a. masyarakat hukum adat

b. masyarakat hukum wilayah (persekutuan desa) dan

c. masyarakat hukum serikat desa (perserikatan desa). ${ }^{41}$

Sejalan dengan perkembangan pemikiran dan orientasi hidup, selain pelapisan sosial yang tradisional yang berdasarkan keturunan di atas, pada umumnya di masyarakat suku Sasak Sade terdapat pelapisan sosial seperti pelapisan sosial berdasarkan kedudukan dan kemampuan ekonomi. Namun demikian faktor usia tetap menjadi ukuran. Menghormati orang tua atau yang seusia sangat diperhatikan dan ditaati oleh masyarakat Sasak Sade. Hal ini tampak dalam hubungan dengan kekerabatan di lingkungan pergaulan dan rumah tangga. ${ }^{42}$

\footnotetext{
${ }^{39}$ Bushar Muhammad, Asas-asas Hukum ..., (Jakarta: Pradnya Paramita, 1983), h. 35.

${ }^{40}$ Bushar Muhammad, Asas-asas Hukum...,h. 36.

${ }^{41}$ Bushar Muhammad, Asas-asas Hukum ...,h. 37.

${ }^{42}$ Morena Cindo dan Andarini Saptika, Adat Istiadat Pernikahan Suku Sasak, (Jakarta: Wadah Ilmu, 2011), h. 6.
} 
Hubungan garis keturunan terbentuk atas dasar pertalian darah dan perkawinan. Hubungan keluarga dari saudara merupakan hubungan kekerabatan dalam arti biologis yang dijalin atau dasar satu sumber darah, yaitu dari orang tua yang sama. Sedangkan hubungan kekerabatan dengan perkawinan merupakan hubungan dalam arti sosiologis yang terjadi karena adanya perkawinan. Rumpun kerabat (keluarga) dibangun atas pandangan kosmogini segi empat yang dikenal dengan empat generasi orang tua (nenek), empat garis anak cucu, dan empat lapis sepupu dari satu talian darah. Pungutan garis kekerabatan ini sering dirangkai dengan mengadakan acara-acara seperti acara keluarga yang diselenggarakan pada acara adat perkawinan, kematian anggota, dan khitanan anak, serta daur hidup keluarga baru dan pada acara keagamaan seperti maulid nabi dan isra' mi'raj.

Dalam sistem kemasyarakatan ini terdapat beberapa pengertian pokok antara pelapisan sosial, pemerintahan, organisasi sosial, dan sistem kekerabatan. ${ }^{43}$ Sistem perkawinan yang dianut oleh suku Sasak Sade lebih mengarah ke sistem endogami. Bahkan di beberapa tempat, terutama pada masa lampau, sistem endogami dilaksanakan secara ketat yang kemudian melahirkan kawin paksa dan pengusiran terhadap terutama anak gadis. Namun sistem perkawinan eksogami tidak diharamkan oleh adat. Sebenarnya terdapat tiga sistem perkawinan adat Sasak Sade yaitu, perondongan (perjodohan), mepadik lamar, dan merariq atau selarian.

Proses perkenalan dalam masyarakat adat Sasak Sade lahir dari proses sosial yang berawal dari sebuah acara adat. Jarang masyarakat adat Sasak Sade menaruh ketertarikan khusus pada seseorang karena sebuah perjumpaan yang tidak disengaja, sepintas atau lainnya. Perkenalan biasanya menjadi bagian juga dari acara adat Sasak, misalnya dalam persiapan perkawinan adat Sasak Sade ataupun pada saat ada yang meninggal. Saat inilah rowah begawe itu dilakukan pada bagian tertentu dari beganve inilah akan diselipkan kegiatan pendekatan bagi para terune dan dedare, baik yang sudah saling kenal maupun yang belum kenal sama sekali. Perkawinan adat Sasak Sade yang melalui proses panjang dan penuh dengan aturan nilai-nilai dan etiak sosial, sebenarnya mampu meminimalisir perkawinan dini yang banyak merugikan pihak perempuan. Dalam kenyataannya kelas-kelas sosial dihubungkan dengan kemungkinan kehidupan yang lebih baik. Kedudukan seseorang dalam suatu kelas sosial tertentu menentukan kemungkinan kesejahteraan yang diperoleh dan sebagainya.

\section{Kesimpulan}

Dari uraian di atas, adat perkawinan Endogami yang dilakukan oeh masyarakat Sade yang ada di Rembitan Lombok Tengah adalah suatu adat kebiasaan yang dilakukan oleh masyarakat Sasak bagian selatan secara turun

\footnotetext{
${ }^{43}$ Morena Cindo dkk, Adat Istiadat Pernikahan...,h. 25.
} 
temurun. Proses perkawinan adat endogami pada dasarnya tidak jauh berbeda dengan perkawinan masyarakat Sasak pada umumnya. Perkawinan dilakukan hanya dengan kerabat dekat atau serumpun yang berada dalam dusun tersebut. Perkawinan dilakukan mulai dari semenjak ia saling kemeleq, tepedait, selanjutnya dilakukan ajang beberayean atau bepenyayang (pacaran), dan tahap terakhir yang mereka lakukan adalah menikah (merariq). Hal itu dilakukan karena didorong oleh beberapa faktor yaitu, budaya yang sangat kuat diantara keluarga, menjaga dan melestarikan kekerabatan, untuk menjaga harta kekayaan atau warisan, dan mewarisi nasihat orang tua.

Perkawinan endogami ditinjau dari hukum Islam dapat diklasifikasikan menjadi dua macam. Pertama, ada yang dapat diterima dan tidak melanggar aturan dalam Islam maupun hukum adat, yaitu seperti perkawinan dalam bentuk banjar belele, berempung puntiq, gentiq karang ulu ataupun dengan cara tepedait. Kedua, ada yang bertentangan dan tidak dapat diterima hukum Islam maupun hukum adat setempat, yaitu perkawinan endogami yang disebut dalam bahasa Sasak beseloq elong basong atau perkawinan silang yang populernya dalam Islam disebut nikah shigar.

\section{Daftar Pustaka}

Abdurrahman. Kompilasi Hukum Islam di Indonesia. Jakarta: Akademika Pressindo. 2004.

Ahmad Wardi Muslich. Hukum Pidana Islam. Jakarta: Sinar Grafika.2005.

Al-Tirmizi. Sunan At-Tirmizi. Lubnan: Darul Kutub Al-'Ilmiyah Beirut. 1971.

Beni Ahmad Saebani. Metode Penelitian Hukum. Bandung: Pustaka Setia. 2009.

Departemen Agama Republik Indonesia. Al-Qur'an dan Terjemahnya. Bandung: J-ART. 2005.

Hidayatullah. Adat Ponan di Kecamatan Moyo Hilir Kabupaten Sumbawa ditinjau dari Hukum Islam, Mataram: IAIN Fakultas Syari'ah. 2007.

IAIN Mataram.Pedoman Penulisan Skripsi Iain Mataram, Mataram: IAIN 2011. Ibnu Majah.Sunan Ibnu Majah. Lubnan: Darul Kutub Al-'Ilmiyah Beirut. 1971. 
Imam Bukhari. Shahih Bukhari. Lubnan: Darul Kutub Al-'Ilmiyah Beirut. 1992.

Imam Muslim.Shabih Muslim. Lubnan: Darul Kutub Al-'Ilmiyah Beirut. 1971.

Kurdap Selake. Mengenal Budaya dan Adat Istiadat Komunitas Suku Sasak di Desa Tradisional Sade, Mataram: Dinas Kebudayaan dan Parawisata Provinsi Nusa Tenggara Barat. 2011.

Lexy J. Moleong. Prosedur Penelitian Suatu Pendekatan KualitatifBandung: Rineka Cipta. 2006.

Lukman Hakim. Perkawinan Adat Sumbawa di Desa Labuban Burung Kecamatan Alas Kabupaten Sumbawa Menurut Pandangan Islam, Mataram: IAIN Fakultas Syari'ah. 2000.

M. Shabbag. Hadiah Cinta; Kiat Islami Merncanakan dan Membina Rumab Tangga Bahagia Selamanya.Jakarta: Bania Publishing. 2011.

M. Yusuf H. Ibrahim. Tinjauan Hukum Islam Terbadap Pelaksanaan Perkawinan Menenurut Adat Sasake (Studi di Desa Kateng Lombok Tengab), Mataram: IAIN Fakultas Syari'ah. 2001.

Marzuki.Metodologi Riset. Yogyakarta: PT. Prasetya Widia Pratama. 2000.

Nasution S. Metode Penelitian NaturalistikKualitatif. Bandung: PT.Tarsito. 2003.

Rahmat Hakim. Hukum Pidana Islam. Bandung: Pustaka Setia. 2000.

Sayyid Sabiq. Fikih Sunah 9. Bandung: Al-Ma’arif, 1984.

Suharsimi Arikunto. Prosedur Penelitian Suatu Pendekatan Praktek. Jakarta: Bineka Cipta. 1998.

Sulaiman Rasjid. Fiqib Islam. Bandung: Sinar Baru Algensindo. 2006.

Undang-undang RI No. 1 Tahun 1974 Tentang Perkawinan \& Kompilasi Hukum Islam serta PERPU Tahun 2009 Tentang Penyelenggaraan Ibadah Haji. Surabaya : Kesindo Utama. 2010. 
Adat Perkawinan Endogami Masyarakat Sade 